\title{
Chiari IV Malformation, the Lückenschädel and Sagittal Craniosynostosis Association: Case Report and Literature Review
}

\section{Associação entre malformação de Chiari IV, Lückenschädel e craniossinostose sagital: relato de caso e revisão de literatura}

Pedro Radalle Biasi $^{1}$ Laura Regyna Toffoli Roso ${ }^{2}$ Grégori Manfroi ${ }^{2}$ Rafael Augusto Espanhol ${ }^{1}$ Timóteo Abrantes de Lacerda Almeida ${ }^{1}$ Matheus Pintos Brunet ${ }^{1}$ Wellington César de Souza ${ }^{1}$ Eduardo Felipe Martinelli Baldissera ${ }^{1}$ Bruna Constantino Rech ${ }^{3}$ Naiana Posenato ${ }^{4}$ Marcelo Ughini Crusius ${ }^{5}$

${ }^{1}$ Neurosurgery Residence, Hospital São Vicente de Paulo, Passo Fundo, RS, Brazil

2 Medical Student, Universidade de Passo Fundo, Passo Fundo, RS, Brazil

${ }^{3}$ Neurology Resident, Hospital São Vicente de Paulo, Passo Fundo, RS, Brazil

${ }^{4}$ Neurologist, Instituto de Neurologia e Neurocirurgia de Passo Fundo, Passo Fundo, RS, Brazil

5 Neurosurgeon, Instituto de Neurologia e Neurocirurgia de Passo Fundo, Passo Fundo, RS, Brazil
Address for correspondence Pedro Radalle Biasi, MR, Av. Sete de Setembro, 65, ap 101, Centro, Passo Fundo, RS, Brazil 99010-121 (e-mail: pedrobiasi@doctor.com).

Arq Bras Neurocir 2016;35:74-77.

\section{Abstract \\ Keywords \\ - Chiari malformation \\ - Lückenschädel \\ - craniosynostosis \\ - hydrocephalus \\ - ventriculostomy}

The association between Lückenschädel and craniosynostosis is unusual and unknown. Genetic origin is a possibility, representing one of many possible phenotypes for mutation. To the best of our knowledge, the association of such anomalies in a type IV Chiari malformation has never been reported before. The authors present the case of a patient with obstructive hydrocephalus, diagnosed with Chiari IV malformation associated with Lückenschädel and sagittal craniosynostosis. The Lückenschädel is the bone abnormality least commonly associated with Chiari malformation. It consists of a defect in the bones of membranous origin that form the cranial vault. This anomaly arises from periosteal dysplasia, and is characterized by rounded and irregular gaps in the skull, bound by bony ridges. Craniosynostosis is due to premature fusion of the cranial sutures and is sometimes associated with the Chiari complex of malformations. The diagnostic of Lückenschädel and craniosynostosis is done by imaging, through which the skull assumes the aspect of a hive, characteristic of Lückenschädel and it is possible to see the premature fusion of the sutures. The Lückenschädel usually does not require treatment because of spontaneous resolution; whereas, craniosynostosis received

May 2, 2015

accepted

August 28, 2015

published online

December 29, 2015
DOI http://dx.doi.org/

10.1055/s-0035-1570365. ISSN 0103-5355.
Copyright $\odot 2016$ by Thieme Publicações License terms

Ltda, Rio de Janeiro, Brazil
(1) $\Theta \circledast$ 


\section{Resumo \\ Palavras-chave \\ - malformação de Chiari \\ - Lückenschädel \\ - craniossinostose \\ - hidrocefalia \\ - ventriculostomia \\ O Lückenschädel e a craniossinostose são uma associação incomum e pouco conhe- cida, com possível origem genética, o que representa um dos muitos fenótipos possíveis para uma mutação. Até onde sabemos, a associação destas anomalias em um caso de malformação de Chiari tipo IV não foi relatada antes. Os autores apresentam o caso de um paciente com hidrocefalia obstrutiva, que foi diagnosticado com malformação de Chiari tipo IV associada com Lückenschädel e craniossinostose sagital. O Lückenschädel é a anormalidade óssea menos comum associada com a malformação de Chiari. É constituída por um defeito nos ossos de origem membranosa que formam a abóbada craniana. Esta anomalia surge de displasia do periósteo e é caracterizada por falhas arredondadas e irregulares no crânio, delimitadas por cristas ósseas. A craniossinostose se deve à fusão prematura das suturas cranianas e é por vezes associada com o complexo de malformações de Chiari. Os diagnósticos de Lückenschädel e craniossinostose são feitos por imagem, onde o crânio assume um aspecto de colmeia, característico de Lückenschädel, e é possível ver a fusão prematura das suturas. O Lückenschädel geralmente não requer tratamento por causa de resolução espontânea e craniosynostosis necessita de cirurgia para fins estéticos e funcionais. A malformação de Chiari IV só requer tratamento quando resulta em siringomielia ou hidrocefalia.}

warrants surgery for aesthetic and functional reasons. The Chiari malformation IV only requires treatment when it results in syringomyelia or hydrocephalus.

\section{Introduction}

Lückenschädel and craniosynostosis are an unusual and little-known association with possible genetic origin, representing one of many possible phenotypes for a mutation in the FGFR2 gene. ${ }^{1-4}$ The Chiari malformations are a complex group of anatomic anomalies that usually is associated either to the Lückenschädel or to craniosynostosis. To the best of our knowledge, the association between these three anomalies has not been reported before. ${ }^{1,2,4-8}$ In this study, the authors aim to describe this extremely rare association and to provide a review of the literature.

\section{Case Report}

The study involved a male infant, eight months old, evolving with increased head circumference and developmental delay. We performed a computed tomography (CT) scan and saw evidence of obstructive tetraventricular hydrocephalus and multiple bone defects in the cranial vault, as well as premature fusion of the sagittal suture, consistent with a diagnosis of Lückenschädel and sagittal craniosynostosis (-Figs. 1 and 2). Magnetic resonance imaging (MRI) of the skull showed a reduced size of the posterior fossa, lowsetting tentorium and torcular Herophili, and herniation of the cerebellar tonsils through the foramen magnum of about $7 \mathrm{~mm}$ (-Figs. 3 and 4). We performed a third endoscopic ventriculostomy with resolution of hydrocephalus for further programming of posterior fossa decompression and treatment of synostosis. The patient remains stable until the time of this report.

\section{Discussion}

The complex of Chiari malformations was first described in 1883 by Cleland, and graded in 1891 by the Austrian pathologist Hans Chiari. It denotes a heterogeneous group of anatomical anomalies involving the posterior cranial fossa,

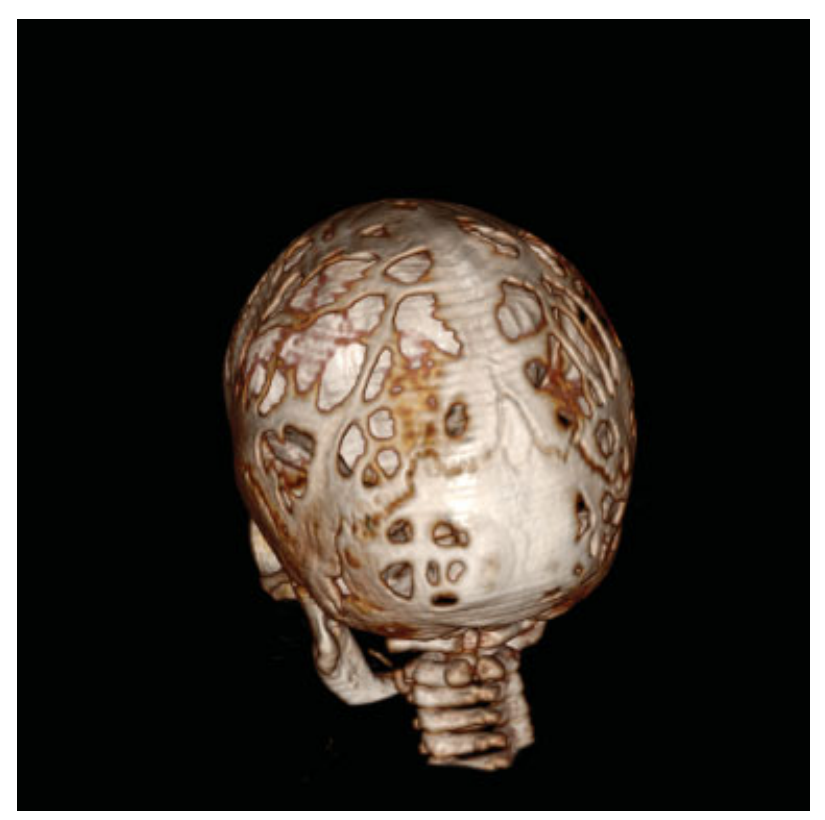

Fig. 1 3-D reconstruction CT scan depicts the sagittal craniosynostosis and the multiple bone defects of Lückenschädel. 


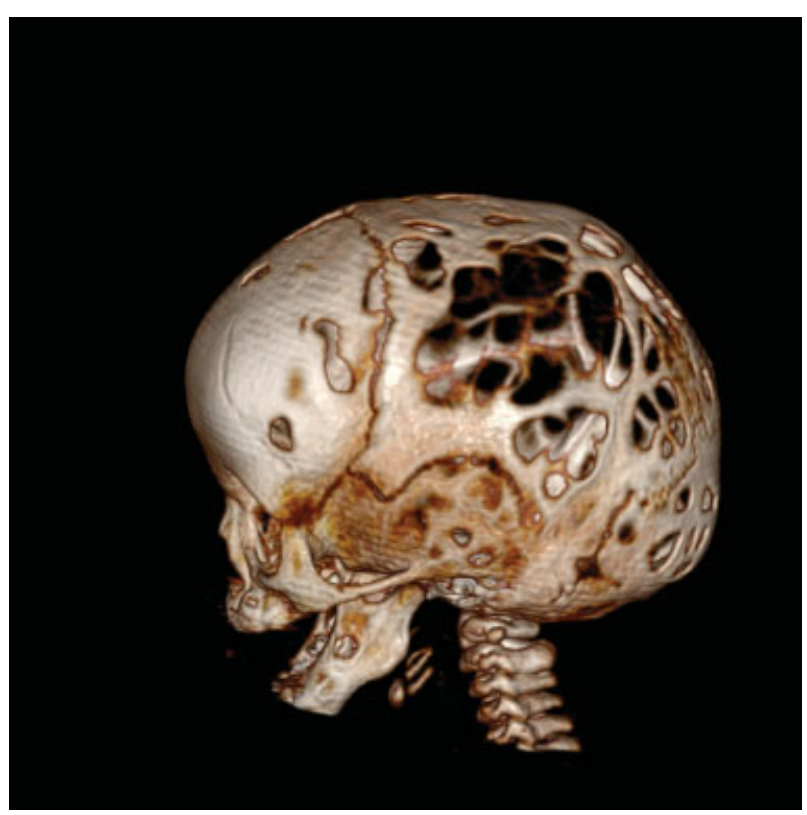

Fig. 2 3-D reconstruction CT scan depicts the multiple bone defects of Lückenschädel.

the cerebellum, brain stem, and cranial-cervical junction, with or without changes in the lower cord. Classically, there are four accepted subtypes of malformations. Types 1 and 2 are the most prevalent, with an incidence ranging from 1 to 5 thousand births. Recently, authors have proposed subtypes 1.5 and zero, although this has not yet become widespread. $^{5-10}$

Subtype 4, presented by the authors, is uncommon, and rarely is associated with tonsillar herniation. It is character-

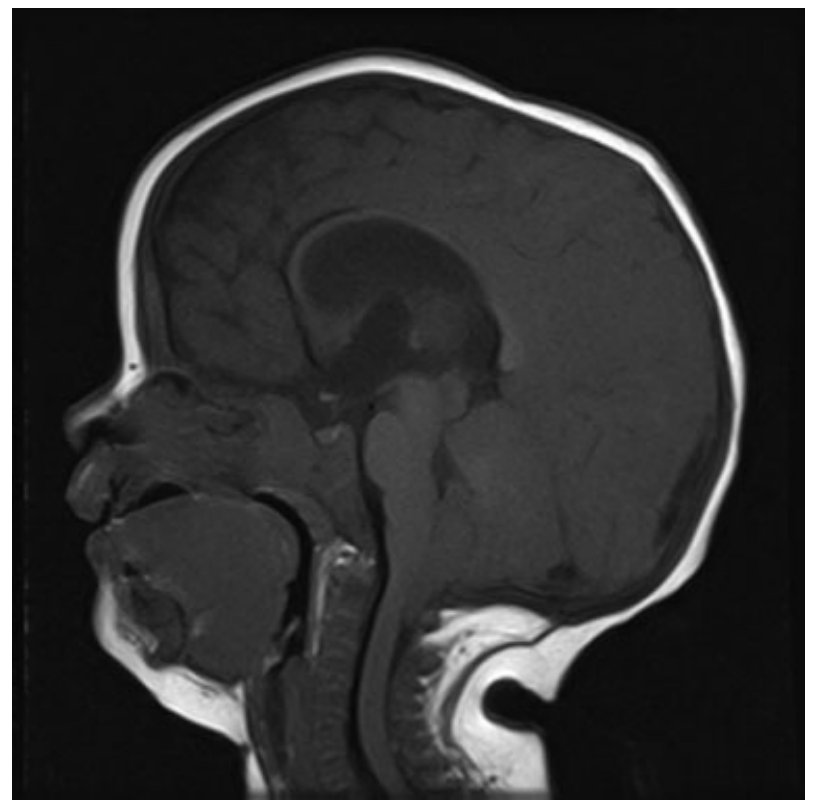

Fig. 3 Sagittal T1W MRI depicts the reduced size of the posterior fossa, low-setting torcular herophili, and herniation of the cerebellar tonsils through the foramen magnum. ized by a small posterior fossa, with cerebellar hypoplasia, hypoplasia of the tentorium, and low-setting torcular herophili. $^{5-8}$

The Lückenschädel is one bone abnormality that can be found in association with Arnold-Chiari (assimilation of Atlas, atlantoaxial dislocation, Klippel-Feil anomaly, platibasia, basilar invagination), being the most unusual and generally associated with subtype 2 , the most serious of the complex. This condition reaches $82 \%$ incidence in some series; however, the frequency of association with other subtypes of Chiari malformations is not known. ${ }^{1,2,11,12}$

Also called craniolacunia, lacunar skull, or fenestrated skull, the Lückenschädel consists of a defect in the bones of membranous origin that form the cranial vault. This anomaly is due to periosteal dysplasia, and is characterized by rounded and irregular gaps in the skull, bounded by bony ridges. Pathologically such failures are completely devoid of bony structure formed by only a membranous diaphragm of periosteum and dura mater. The same defect is not found in the skull base bones, which have cartilaginous origin. ${ }^{1-4,11-16}$

The association between Lückenschädel and craniosynostosis is already known, but uncommon, occurring in $10 \%$ of cases of craniosynostosis. It is likely caused by mutations in the FGFR2 gene (fibroblast growth factor receptor 2) involved in the genesis of craniosynostosis, which have been found in cases of craniolacunia, raising suspicion that mutations in different exons would be responsible for different phenotypes. ${ }^{4,17-22}$ This would explain the association in the present case.

The Lückenschädel and craniosynostosis diagnoses are done through imaging studies, both X-ray and computed tomography, in which is possible to see the bone defects and fusion of the cranial sutures. When examining X-rays or CT with 3D

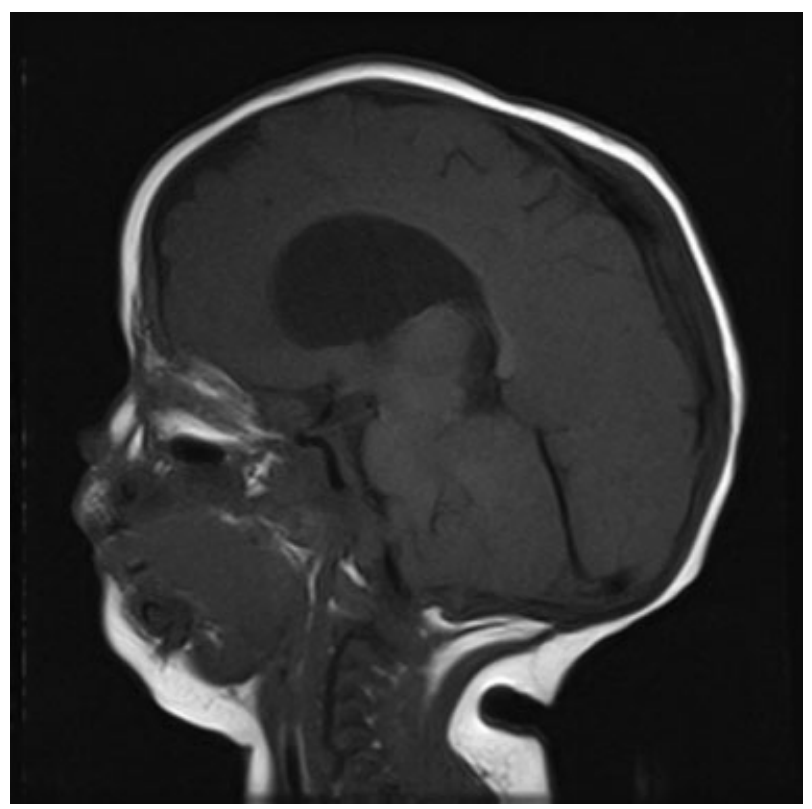

Fig. 4 Sagittal T1W MRI depicts the reduced size of the posterior fossa and low-setting tentorium. 
reconstruction, the skull assumes the aspect of a hive, which is a typical characteristic of Lückenschädel. ${ }^{1-4,11-13,15,16,21,23,24}$

This anomaly usually does not require treatment because the ossification tends to normalize between the fourth and sixth month of life, and does not directly reflect in brain development. ${ }^{1,3,4}$ Given its spontaneous and early resolution, it is not seen in adults, which contributes to the low rate of diagnosis of this condition. ${ }^{1,3,4}$ The Chiari malformation type IV also tends to be asymptomatic, except for the few cases where there may be tonsillar herniation, determining syringomyelia and/or hydrocephalus. In this case, neurosurgical intervention is required, as in the present case. ${ }^{5-7}$

Craniosynostosis implies surgery for aesthetic and functional purposes and should be performed as early as possible after diagnosis. $^{23,24}$

The association between Chiari 4 malformation, Lückenschädel and craniosynostosis is extremely unusual, being so little known and diagnosed; however, newborn imaging studies may increase the diagnostic rate of these diseases and better guide the medical care of such cases.

\section{References}

1 Vigliani MB. Luckenschadel skull: a forgotten entity. Obstet Gynecol 2008;111(2 Pt 2):562-565

2 Tajima M, Yamada H, Kageyama N. Craniolacunia in newborn with myelomeningocele. Childs Brain 1977;3(5):297-303

3 Rio CE, Pinckney LE, Kennedy LA. Craniolacunia without associated anomalies. Neuroradiology 1981;22(3):155-157

4 Vogt EC, Wyatt GM. Cranilacunia (Lückenschädel) - a report of 54 cases. Anals of thw Twenty-fifth Annual Meeting of the Radiological Society of North America; 1939 december 11-15; Atlanta, USA

5 Sarnat HB. Disorders of segmentation of the neural tube: Chiari malformations. Handb Clin Neurol 2008;87:89-103

6 Carmel PW, Markesbery WR. Early descriptions of the ArnoldChiari malformation. The contribution of John Cleland. J Neurosurg 1972;37(5):543-547

7 Pearce JM. Arnold chiari, or "Cruveilhier cleland Chiari" malformation. J Neurol Neurosurg Psychiatry 2000;68(1):13

8 Schijman E. History, anatomic forms, and pathogenesis of Chiari I malformations. Childs Nerv Syst 2004;20(5):323-328

9 Tubbs RS, Elton S, Grabb P, Dockery SE, Bartolucci AA, Oakes WJ. Analysis of the posterior fossa in children with the Chiari 0 malformation. Neurosurgery 2001;48(5):1050-1054, discussion 1054-1055

10 Tubbs RS, Iskandar BJ, Bartolucci AA, Oakes WJ. A critical analysis of the Chiari 1.5 malformation. J Neurosurg 2004;101(2, Suppl) 179-183

11 Tajima M, Yamada H, Kageyama N, Nakamura S. [Craniolacunia in newborns with myelomeningocele and encephalocele (author's transl)]. No Shinkei Geka 1978;6(10):975-979

12 Coley BD. Ultrasound diagnosis of luckenschadel (lacunar skull). Pediatr Radiol 2000;30(2):82-84

13 Shigemori M, Honda E, Shojima K, Nagayama K, Takajyo N. [Two cases of craniolacunia associated with meningocele and meningoencephalocele (author's transl)-a1]. No Shinkei Geka 1976; 4(8):785-790

14 Stein S, Schut L, Borns P. Lacunar skull deformity (Lückenschädel) and intelligence in myelomeningocele. J Neurosurg 1974;41(1): $10-13$

15 Gardner WJ, Poolos PN. Craniolacunia: The result of embryonal hydrocephalus? Teratology 1976;13(2):189-190

16 Chaudhari AM, Karas CS, Baig MN, Elton SW. Unique defect representing features of Chiari type III and IV malformations. Pediatr Neurosurg 2008;44(6):513-514

17 Reardon W, Winter RM, Rutland P, Pulleyn LJ, Jones BM, Malcolm S. Mutations in the fibroblast growth factor receptor 2 gene cause Crouzon syndrome. Nat Genet 1994;8(1):98-103

18 Schell U, Hehr A, Feldman GJ, et al. Mutations in FGFR1 and FGFR2 cause familial and sporadic Pfeiffer syndrome. Hum Mol Genet 1995;4(3):323-328

19 Liu J, Kwon T-G, Nam HK, Hatch NE. Craniosynostosis-Associated Fgfr2C342Y Mutant Bone Marrow Stromal Cells Exhibit Cell Autonomous Abnormalities in Osteoblast Differentiation and Bone Formation. BioMed Research International 2013;2031:11

20 Kelleher FC, O'Sullivan H, Smyth E, McDermott R, Viterbo A. Fibroblast growth factor receptors, developmental corruption and malignant disease. Carcinogenesis 2013;34(10):2198-2205

21 Steinberger D, Müller U, Jünger TH, Howaldt HP, Christophis P. Mutation of FGFR2 (cys278phe) in craniolacunia and pansynostosis. J Med Genet 1999;36(6):499-500

22 Ito S, Sekido K, Kanno H, et al. Phenotypic diversity in patients with craniosynostoses unrelated to Apert syndrome: the role of fibroblast growth factor receptor gene mutations. J Neurosurg 2005;102(1, Suppl)23-30

23 Renier D, Lajeunie E, Arnaud E, Marchac D. Management of craniosynostoses. Childs Nerv Syst 2000;16(10-11):645-658

24 Abe H, Ikota T, Akino M, Kitami K, Tsuru M. Functional prognosis of surgical treatment of craniosynostosis. Childs Nerv Syst 1985; 1(1):53-61 